\title{
Selection of Sustainable Materials for Energy Savings of Infrastructure-Transportation Project in Ahmedabad, India Using BIM and FCM
}

\author{
Hirakraj Bapat, "Debasis Sarkar and Rajesh Gujar
}

First submission: 11 July 2020; Accepted: 28 October 2020; Published: 8 December 2021

To cite this article: Hirakraj Bapat, Debasis Sarkar and Rajesh Gujar (2021). Selection of sustainable materials for energy savings of infrastructure-transportation project in Ahmedabad, India using BIM and FCM. Journal of Construction in Developing Countries, 26(2): 135-161. https://doi.org/10.21315/jcdc2021.26.2.7.

To link to this article: https://doi.org/10.21315/jcdc2021.26.2.7

\begin{abstract}
This study aims to develop a methodology for the selection of sustainable building materials for the reduction of embodied and operational energy for a complex infrastructure transportation project, i.e., elevated metro rail station of Ahmedabad, India by application of building information modelling (BIM) and factor comparison method (FCM). Evaluation of the alternative building materials and designs to obtain the best energy efficiency has been carried out using Revit Architecture 2018 and Green Building Studio. The achieved average embodied energy savings is about $73 \%$, which is by the suggested alternative materials instead of existing ones. By application of FCM, which is a multi-criteria decision making (MCDM) technique, it has been observed that the polished Kota-stone flooring, stone-floor-tile cladding, toughened fibre-glass ceiling and insulated fibre-glass door appear to be the most feasible sustainable material for flooring, wall cladding, ceiling, openings and fenestrations for the design of the metro rail station box in Ahmedabad, India. This study contributes significant knowledge in the field by highlighting the application of BIM as a tool for sustainable development and recommends a few alternate building materials and sustainable designs which would result in the reduction of energy usage for the metro-rail-station and other building structures leading to a sustainable future.
\end{abstract}

Keywords: Building information modelling, Energy simulation, Energy savings, Energy efficient metro rail station, Factor comparison method, Sustainability

\section{INTRODUCTION}

The construction and building segment has a significant impact on the global environment because of its massive energy consumption (Shoubi, Bagchi and Barough, 2015). A study carried out by Bapat and Sarkar (2019) shows that there are around 549 active metro lines consisting of $11,300 \mathrm{~km}$ of infrastructure and 9,200 metro-stations in India. It also highlights that the fossil fuels are largely used to produce more than $80 \%$ of the current energy demand. Despite huge investments in developing renewable and sustainable energy capacities, the world energy consumption has hardly decreased. It also stated that buildings constitute almost $40 \%$ of total world energy consumption.

Department of Civil Engineering, School of Technology, Pandit Deendayal, Petroleum University, Gandhinagar, INDIA

*Corresponding author: debasis.sarkar@sot.pdpu.ac.in 
Building information modelling (BIM) is an emerging tool used to facilitate energy-efficient designs of buildings using three-dimensional (3D) modelling and information management throughout the project life cycle (Lu et al., 2017). Multi-disciplinary information can be incorporated into the 3D model and can also be managed according to the user requirements. Recently, an innovative development of BIM has provided opportunities to support an energy-efficient practice, known as "green BIM". Green BIM is defined as a model-based process of generating and managing coordinated and consistent building data that facilitates the accomplishment of established sustainability goals (Wong and Zhou, 2015). It facilitates multiple evaluations and performance analysis such as carbon emissions, construction management, daylight analysis, operational and embodied energy usage.

The thermal aspect is the main point of investigation as it involves a significant amount of operational energy consumption of the building. Every building consists of a chain of components with respect to its thermal dissipation. Building design and surrounding environmental conditions are responsible for changes in the rate of energy dissipation (Jelle, Gustavsen and Baetens, 2010; Laine, Hanninen and Karola, 2007). A significant amount of energy savings can be achieved by modifying building materials in terms of heat exchange. Utilisation of better alternate building material with better thermal insulation characteristics leads to the minimisation of heating and cooling loads, resulting in cost savings and reducing greenhouse gas emissions through optimum energy consumption (Shoubi, Bagchi and Barough, 2015; Reddy and Jagadish, 2003).

Energy-efficient buildings must include processes that minimise the energy consumption in terms of operational energy, which is the energy required during the operation phase of the building used for operations like heating, cooling, power supply to fixtures and embodied energy which is used in the extracting, manufacturing, logistical and installation process. To increase the energyefficiency, high efficiency building elements like insulation walls, ceiling, and floors should be used, leading to operating energy optimisation (Schlveter and Thessling, 2009).

A similar problem is also faced during the implementation of a conventional planning process when performance and energy analysis are to be carried out after the design of the project and documents have been submitted (Chong et al., 2017). Decisions taken in the design phase before construction to ensure a sustainable approach towards project design are significant, because decisions made in the execution or maintenance phase, i.e., during or after construction, result in inefficient and costly rework modification processes to change the design and construction to obtain the specific performance and energy goals. The information of building orientation, façade, building materials, systems, etc., is essential for the assessment of the energy performance analysis of the project in the design phase (Schlveter and Thessling, 2009). Several attempts to design zero energy buildings have been made by several researchers. Hernandez and Kenny (2008) were the main proponents of a study with respect to designing zero energy buildings. Their work was associated with low energy passive architecture with a perspective of the building life cycle.

The primary objective of this study is to spot various sustainable design alternatives to save energy in terms of operational and embodied energy by utilising BIM. This study would also help to identify better sustainable alternative 
materials which are likely to have a huge impact on building performance ensuring a reduction in the embodied and operational energy for a building facility like a metro rail station box of Ahmedabad, a megacity in India.

\section{LITERATURE REVIEW}

BIM is an emerging technological and procedural shift within Architecture, Engineering, and Construction (AEC) (Noor and Yi, 2018; Olowa, Witt and Lill, 2019). BIM is required for the development of buildings with increased sustainability and productivity on construction sites (Azhar and Brown, 2009). Khanzadi, Sheikhkhoshkar and Banihashemi (2020) in their study on identification of BIM capabilities in key performance indicators (KPIs) of construction projects in Iran, observed that sustainable construction is one of the top three KPIs, which affects to a great extent the construction projects. Thus BIM can be very effectively applied as a tool for sustainable development. A number of different energy modelling techniques has been applied to numerous studies in an attempt to predict future energy usage, including the statistical analysis of building consumption data (Catalina, Virgone and Blanco, 2008; Ekici and Aksoy, 2009; Olofsson, Andersson and Sjögren, 2009; Pan, Yin and Huang, 2008). Many researchers have focused on the studies pertaining to energy-efficiency in buildings (Ayarkwa et al., 2014). A study by Adewunmi, Alister and Thabethe (2019) revealed that the biggest barrier to the implementation of energy efficient practices was the cost of such implementation. Alwan and Jones (2014) have also stated that construction should be focused on the operational and embodied energy of buildings because of better suitability and flexibility of the design process. Pezeshki, Soleimani and Darabi (2019) reviewed the building energy modelling (BEM) development using different methodologies based on BIM data. The authors provide seven types of direction to examine building energy prediction and estimation, building energy consumption, building energy optimal design, building energy evaluation, building energy efficiency, building energy management, and building energy optimisation. Westfall, Nanduri and Taylor (2003) developed a different methodology to calculate energy consumption based on the statistics and simulation. Some of them are based on statistics and others on simulation.

For energy consumption, Ng, Persily and Emmerich (2015) observed that a large percentage of building energy mislaying occurs due to the leakage in the building envelope; the performance efficiency of the building envelope and equipment of the heating, ventilation, and air-conditioning (HVAC) systems can reduce a considerable amount of energy consumption of buildings. Sartori and Hestnes (2007) studied 60 reports to identify the importance of embodied and operational energy. Following their work, Hammond and Jones (2008) carried out their research primarily on the embodied energy of the construction materials. Their work also focussed on assessing the carbon content of the construction materials that considered for embodied energy computation.

Zhang, Nizam and Tian (2018) proposed a methodology to integrate embodied energy and to analyse the embodied energy of the constituent materials and also the energy consumed during transportation and construction. Khasreen, Philip and Menzies (2009) discussed the methodology of life cycle analysis and reviewed some applications from the perspectives of building and 
components. Ramesh, Prakash and Shukla (2010) concluded that building life cycle energy can be significantly reduced by minimising its operational energy through the use of active and passive technologies. Most of the above mentioned studies were reviewed by Yung, Lam and Yu (2013), who concluded that different authors used different methodologies of life cycle analysis in building due to lack of data and also revealed that most of the embodied energy calculation is based on gross floor area rather than the volume of building materials.

BIM in green building enables sustainable designs, allowing architects and engineers to integrate and analyse building performance. Reviewing the available literature for the past one and a half decades, it has been observed that, attempts to reduce embodied energy or operational energy were made separately and only in terms of selecting or replacing specific alternative building materials. Very few researchers have attempted to take up a specific case study of an infrastructure building facility to reduce its operational and embodied energy for the whole building facility. Further, it has been observed that minimal attempts have been made by researchers to work on both operational and embodied energy, and this work is in a very nascent stage. Researchers have worked and made attempts to either reduce operational energy or reduce embodied energy. The present research aims to develop a methodology to reduce both operational and embodied energy and to develop a methodology for the selection of sustainable materials for an infrastructure building facility, which is quite complex in nature, like a metro rail station box for an elevated metro rail corridor construction in Ahmedabad, India.

\section{CASE STUDY}

The case study undertaken for the present research is the elevated metro rail station box located in Ahmedabad, a megacity in India. Phase 1 under construction consists of the north-south corridor of $18.87 \mathrm{~km}$ and the east-west corridor of $21.16 \mathrm{~km}$ totalling to $40.03 \mathrm{~km}$ in which a $33.50 \mathrm{~km}$ section is elevated, while the rest $6.53 \mathrm{~km}$ is underground. Hence, out of a total 32 stations, 28 are elevated, and four are underground as they pass through highly traffic-congested areas. Table 1 shows the project and stakeholder details of the case study. Figure 1 shows the alignment, location, and routes of all the stations with respect to their directional corridors. 
Table 1. Project details of an elevated metro rail station of Ahmedabad metro rail project phase 1

\begin{tabular}{cll}
\hline No. & & \multicolumn{1}{c}{ Details } \\
\hline 1 & Project name & Elevated Metro Rail Station Box Ahmedabad \\
2 & Estimated cost & INR400 million \\
3 & Contractor & Ranjit Buildcon Ltd., Ahmedabad \\
4 & Client & Gujarat Metro Rail Corporation (GMRC) (formerly \\
& & MEGA) on north-south corridor of Ahmedabad \\
5 & Time period & 21 months \\
6 & Total carpet area & 5,740 sq. m \\
7 & Mechanical, electrical, & Siemens India-Siemens AG, Germany \\
& $\begin{array}{l}\text { plumbing, and fire-safety } \\
\text { (MEPF) consultant }\end{array}$ & \\
& Architect & Aarvee Associates JV with K.P. Padmanabha \& \\
9 & Structural designer & Associates \\
& & Aarvee Associates JV with K.P. Padmanabha \& \\
10 & PMC (Project management & Systra-RITES-Oriental-AECOM JV \\
\hline
\end{tabular}

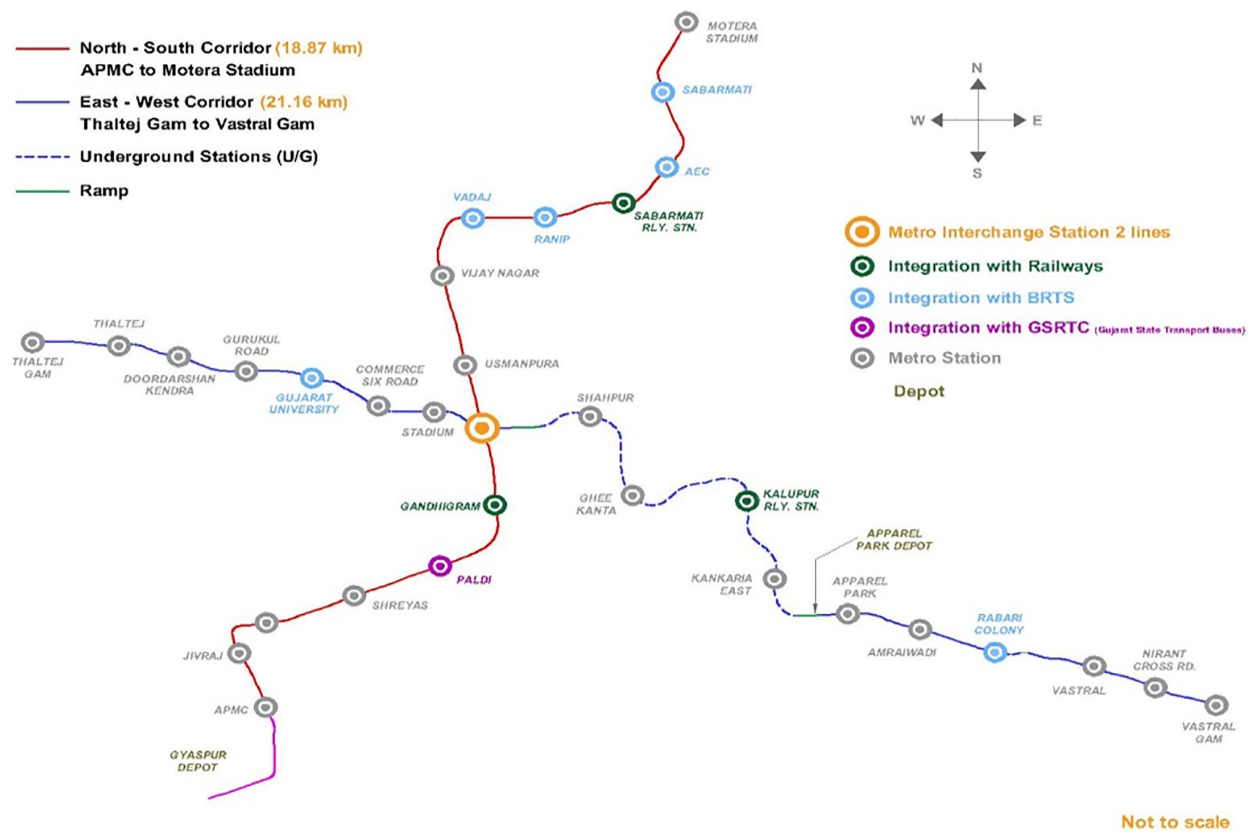

Figure 1. Location and route alignment details of Ahmedabad metro rail project phase 1 (as retrieved from https://www.gujaratmetrorail.com) 


\section{METHODOLOGY}

Several methodologies have been developed to estimate energy consumption. Some of them are based on statistics, while others are based on simulations (Westfall, Nanduri and Taylor, 2003; Sartori and Hestnes, 2007). In general, it is accepted that weather data must be given a careful attention and consideration in forecasting the energy consumption of buildings. Software like Green Building Studio, e-QUEST and Design Builder can combine simplified input wizards with simulation tools for measuring the energy performance of the building facility. All these software programs are capable of developing 3D prototype of the building facility and hence are considered as an integral component of BIM. The interoperability features of all these software programmes enable the development of six-dimensional (6D) modelling or energy modelling through BIM. Some energy simulation software programmes like Energy Plus does not produce 3D models of the building facility by itself, but need to be integrated with Design Builder or Open Studio with plug-in for Google Sketch Up, which are capable of producing 3D models and prototypes.

The present research uses Revit Architecture 2018 software and Green Building Studio as both the software programmes are developed by Autodesk Inc. and thereby are fully compatible with each other. Green Building Studio is a cloud based energy modelling application (AI Ka'bi, 2020). It is a standalone webservice that focuses on reducing the dependency on fossil fuel at early stages of the building design and is also capable to produce high quality energy models in less time and costs compared to other applications (Al Ka'bi, 2020). The 3D architectural and structural drawings can be directly imported to Green Building Studio for energy simulation and modelling. Some limitations of the e-QUEST software include its inability to export geometry to programmes. It cannot carryout thermal comfort calculations and for designing HVAC systems and it is not able to consider the natural ventilation and operable windows. e-QUEST also requires the weather data to be imported from the Green building Studio and design parameters imported from the Revit software. Furthermore, for computation of operational energy, e-QUEST can be used for small to medium sized building facility with moderate level of complexity, whereas the present study involves the computation of operational energy for a complex and large infrastructure facility like metro rail station box for which Green Building Studio is more suitable.

Some limitations of the Design Builder are that it does not support 3D geometry data exchange since no such functionality is present in the interface. It cannot import Energy Plus input files (.idf format). Also, it only supports compact HVAC systems. Comparative study of the energy simulation applications delivered by some software as stated by Al Ka'bi (2020), Reeves, Olbina and Issa (2015), Crawley et al. (2005) and Witte et al. (2001) as presented in Table 2. 
Table 2. Comparative study of energy simulation software as a part of BIM

\begin{tabular}{|c|c|c|c|c|}
\hline \multirow[b]{2}{*}{ Properties } & \multicolumn{4}{|c|}{ Prospective Software } \\
\hline & $\begin{array}{l}\text { Green Building } \\
\text { Studio }\end{array}$ & $\begin{array}{l}\text { Design } \\
\text { Builder }\end{array}$ & e-QUEST & $\begin{array}{l}\text { Energy } \\
\text { Plus }\end{array}$ \\
\hline Compatible with Autodesk Revit & Yes & Yes & Yes & No \\
\hline $\begin{array}{l}\text { Suitability to handle large scale projects } \\
\text { with high level of complexity }\end{array}$ & Yes & No & No & Yes \\
\hline $\begin{array}{l}\text { Ability to import building geometry from } \\
\text { computer-aided design (CAD) software }\end{array}$ & Yes & Yes & Yes & Yes \\
\hline $\begin{array}{l}\text { Ability to export building geometry from } \\
\text { CAD software }\end{array}$ & Yes & Yes & No & Yes \\
\hline Import/export of simulation models & Yes & No & No & No \\
\hline $\begin{array}{l}\text { Complete geometric description of walls, } \\
\text { ceiling, floors, windows, doors and skylights }\end{array}$ & Yes & Yes & Yes & Yes \\
\hline Thermal balance calculations & Yes & Yes & Yes & Yes \\
\hline Human thermal comfort & Yes & Yes & Yes & Yes \\
\hline Hourly energy calculations & Yes & Yes & Yes & Yes \\
\hline Sub-hourly energy calculations & Yes & No & No & Yes \\
\hline Airflow through the windows & Yes & No & No & Yes \\
\hline Wind energy analysis & Yes & No & No & No \\
\hline Natural ventilation & Yes & No & No & No \\
\hline Lighting, and day lighting controls & Yes & Yes & Yes & Yes \\
\hline HVAC systems configuration & Yes & Yes & Yes & Yes \\
\hline $\begin{array}{l}\text { Consideration of natural ventilation and } \\
\text { operable windows for HVAC system }\end{array}$ & Yes & No & No & Yes \\
\hline
\end{tabular}

Source: Al Ka'bi (2020), Reeves, Olbina and Issa (2015), Crawley et al. (2005) and Witte et al. (2001)

According to the drawing plans and materials specifications of the case study building, the building is simulated in Revit Architecture 2018 software. After the simulation, to integrate the Revit Architecture and energy modelling tool like Green Building Studio, zones must be formed for creating various parts of the building. Without creating zones in Revit Architecture, the energy of the building's various spaces cannot be modelled. In fact, the file cannot be exported to the Green Building Studio software. After creating zones, to export the simulation file from Revit to green building studio, the gbXML based export method explained in the following section must be used. This method can be used to export all building specifications defined in Revit to Green Building Studio. By choosing gbXML based export, some basic and necessary assumptions for energy modelling such as location and types of buildings must be established (Shoubi, Bagchi and Barough, 2015). After considering the essential assumptions, the file is exported to the Green Building Studio software for energy modelling and analysis. 
Before implementing the export process, rooms known as zones must be produced to separate the operational spaces of the building required for energy simulation in the Green Building Studio. The other application of the room element is to specify the area and volume of the spaces. In addition to room setting within BIM before exporting the energy model, the location and types of the building must also be defined, since they are significant factors in energy use and can affect the amount of energy consumed. Figure 1 shows the perspective of an export gbXML file and the colours displayed in the model describe surface elements. Table 3 shows the various zones of the metro rail station box for energy analysis.

Table 3. Assumptions for various zones of metro rail station box for energy analysis

\begin{tabular}{|c|c|c|}
\hline No. & Zones & Assumptions \\
\hline 1 & Ticket area & $\begin{array}{l}\text { Number of people involved: } 120 \\
\text { Type of system: Cooling only } \\
\text { Environmental temperature range for comfort: } 27^{\circ} \mathrm{C} \\
\text { Standard operation duration: } 24 \mathrm{~h} / \text { day }\end{array}$ \\
\hline 2 & Staff room & $\begin{array}{l}\text { Number of people involved: } 7 \\
\text { Type of system: Cooling only } \\
\text { Environmental temperature range for comfort: } 27^{\circ} \mathrm{C} \\
\text { Standard operation duration: } 24 \mathrm{~h} / \text { day }\end{array}$ \\
\hline 3 & Security check area & $\begin{array}{l}\text { Number of people involved: } 120 \\
\text { Type of system: Cooling only } \\
\text { Environmental temperature range for comfort: } 27^{\circ} \mathrm{C} \\
\text { Standard operation duration: } 24 \mathrm{~h} / \text { day }\end{array}$ \\
\hline 4 & Entry area & $\begin{array}{l}\text { Number of people involved: } 266 \\
\text { Type of system: Cooling only } \\
\text { Environmental temperature range for comfort: } 27^{\circ} \mathrm{C} \\
\text { Standard operation duration: } 24 \mathrm{~h} / \text { day }\end{array}$ \\
\hline 5 & Exit area & $\begin{array}{l}\text { Number of people involved: } 266 \\
\text { Type of system: Cooling only } \\
\text { Environmental temperature range for comfort: } 27^{\circ} \mathrm{C} \\
\text { Standard operation duration: } 24 \mathrm{~h} / \text { day }\end{array}$ \\
\hline 6 & $\begin{array}{l}\text { Passenger and boarding } \\
\text { area }\end{array}$ & $\begin{array}{l}\text { Number of people involved: } 1000 \\
\text { Type of system: Cooling only } \\
\text { Environmental temperature range for comfort: } 27^{\circ} \mathrm{C} \\
\text { Standard operation duration: } 24 \mathrm{~h} / \text { day }\end{array}$ \\
\hline 7 & Station control room & $\begin{array}{l}\text { Number of people involved: } 8 \\
\text { Type of system: Cooling only } \\
\text { Environmental temperature range for comfort: } 27^{\circ} \mathrm{C} \\
\text { Standard operation duration: } 24 \mathrm{~h} / \text { day }\end{array}$ \\
\hline 8 & Store room & $\begin{array}{l}\text { Number of people involved: } 5 \\
\text { Type of system: Cooling only } \\
\text { Environmental temperature range for comfort: } 27^{\circ} \mathrm{C} \\
\text { Standard operation duration: } 24 \mathrm{~h} / \text { day }\end{array}$ \\
\hline
\end{tabular}


Table 3. Continued

\begin{tabular}{|c|c|c|}
\hline No. & Zones & Assumptions \\
\hline 9 & $\begin{array}{l}\text { Signalling and telecom } \\
\text { room }\end{array}$ & $\begin{array}{l}\text { Number of people involved: } 10 \\
\text { Type of system: Cooling only } \\
\text { Environmental temperature range for comfort: } 27^{\circ} \mathrm{C} \\
\text { Standard operation duration: } 24 \mathrm{~h} / \text { day }\end{array}$ \\
\hline 10 & Rest rooms & $\begin{array}{l}\text { Number of people involved: } 12 \\
\text { Type of system: Cooling only } \\
\text { Environmental temperature range for comfort: } 27^{\circ} \mathrm{C} \\
\text { Standard operation duration: } 24 \mathrm{~h} / \text { day }\end{array}$ \\
\hline 11 & Station manager room & $\begin{array}{l}\text { Number of people involved: } 4 \\
\text { Type of system: Cooling only } \\
\text { Environmental temperature range for comfort: } 27^{\circ} \mathrm{C} \\
\text { Standard operation duration: } 8 \mathrm{~h} / \text { day }\end{array}$ \\
\hline 12 & Maintenance area & $\begin{array}{l}\text { Number of people involved: } 8 \\
\text { Type of system: Cooling only } \\
\text { Environmental temperature range for comfort: } 27^{\circ} \mathrm{C} \\
\text { Standard operation duration: } 24 \mathrm{~h} / \text { day }\end{array}$ \\
\hline 13 & Solar battery area & $\begin{array}{l}\text { Number of people involved: } 4 \\
\text { Type of system: Cooling only } \\
\text { Environmental temperature range for comfort: } 27^{\circ} \mathrm{C} \\
\text { Standard operation duration: } 24 \mathrm{~h} / \text { day }\end{array}$ \\
\hline 14 & $\begin{array}{l}\text { Uninterruptible power } \\
\text { supply (UPS) battery room }\end{array}$ & $\begin{array}{l}\text { Number of people involved: } 4 \\
\text { Type of system: Cooling only } \\
\text { Environmental temperature range for comfort: } 27^{\circ} \mathrm{C} \\
\text { Standard operation duration: } 24 \mathrm{~h} / \text { day }\end{array}$ \\
\hline 15 & Food court & $\begin{array}{l}\text { Number of people involved: } 8 \\
\text { Type of system: Cooling only } \\
\text { Environmental temperature range for comfort: } 27^{\circ} \mathrm{C} \\
\text { Standard operation duration: } 18 \mathrm{~h} / \text { day }\end{array}$ \\
\hline
\end{tabular}

The selection of the sustainable material has been carried out through factor comparison method (FCM), which is one of the basic tools used for multicriteria decision making (MCDM), where it helps to take a decision about the best feasible alternative by means of paired comparison. According to Das and Garcia-Diaz (2001) and Kahya (2018), factor comparison is the most popular and perhaps the most understandable method and widely used in the industry, due to its reliability and accuracy.

Authors strongly believe that this tool may be a very simple tool to understand and use, but produces very effective decisions. Thereby, FCM has been chosen for carrying out decision making for the selection of the sustainable materials. Other pair-wise comparison based methods include analytic hierarchy process (AHP) and analytic network process (ANP). Both these methods though are very popular, the decisions need to be taken based on the relative importance index (RII) for AHP and ideal ratio comprising of the benefits, opportunities, costs and risks for ANP. Fuzzy can be incorporated in both the methods to reduce the vagueness and these methods are termed as Fuzzy AHP and Fuzzy ANP, respectively. There are some distance based methods like Fuzzy TOPSIS and Fuzzy 
VIKOR. In Fuzzy TOPSIS, Fuzzy Positive Ideal Solution (FPIS) and Fuzzy Negative Ideal Solution (FNIS) and also the closeness coefficient (CC) help making decision about choosing the best alternative but amongst limited set of decision makers and alternatives. Fuzzy VIKOR is based on aggregating fuzzy merit that represents distance of the alternatives from the ideal solution. Some other methods include Fuzzy DEMATEL, which is also a MCDM technique for evaluating cause and effect relationships between attributes and alternatives. Amongst all these available MCDM tools, the FCM appeared to be most simple, robust and very effective in decision making.

\section{ANALYSIS AND FINDINGS}

\section{Application of BIM for Energy Management for Design of Metro Rail Station Box}

After opening Green Building Studio software, which is a part of Revit Architecture, it could be seen that it can identify the elements simulated in Revit software. It shows that these software products can be integrated to facilitate simulation and analysis. The coordinates of Ahmedabad location are used to generate the sun path diagram, wind rose diagram, etc. from the available online cloud database of Autodesk Green Building Studio for design-climatic data. Green Building Studio automatically chooses the nearest weather station of the project location to acquire climatic data for simulation.

Before starting the analysis, the building's shadow on various days of the year and also various times of a specified day has been evaluated. First, the weather specification of the building must be loaded based on its location, since different locations have different sun paths and therefore dissimilar shadow positions. After considering the weather location of Ahmedabad, India, the daily and annual sun path can be visualised. This allows the visual interpretation of exactly where the sun is and its impact on the various parts of the building during different times of the day. It can also be helpful in visualising the building's shadow throughout an entire day.

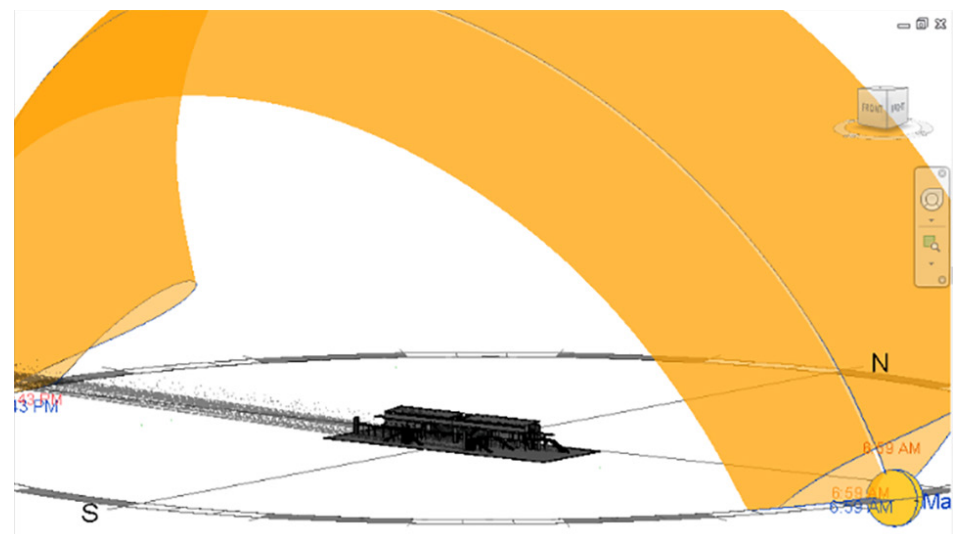

Figure 2. Sun path and shadow analysis (annual) for metro rail station box of Ahmedabad 
Figure 2 illustrates the spherical projection of the sun's position and the sun's daily and annual path around the building. The annual shadow analysis at hourly intervals can be forecasted. Light coming from the south, east, and west will, in many cases, offer the interior direct sunlight throughout the day as the sun pursues its course around the earth. The orientation of the opening, size of opening, building materials, etc., can be designed accordingly to get the maximum possible daylight.

Similarly, by entering the location details like city name, latitude, and longitude in green building studio software for Ahmedabad, India, one can get the annual graphs for temperature, total sky cover, relative humidity, dew point, wind speed, and wind rose diagram. Further, these data also help in deciding the size of openings, the number of openings, characteristics and functionality of the building materials, the orientation of the building for best in class design, and energy efficiency of the metro rail station box leading to more sustainable infrastructure.

The analysis of the case of the metro rail station box for reduction of operational and embodied energy is carried out through wind rose diagram, annual sky cover, annual dew point, and annual wind speed distribution.

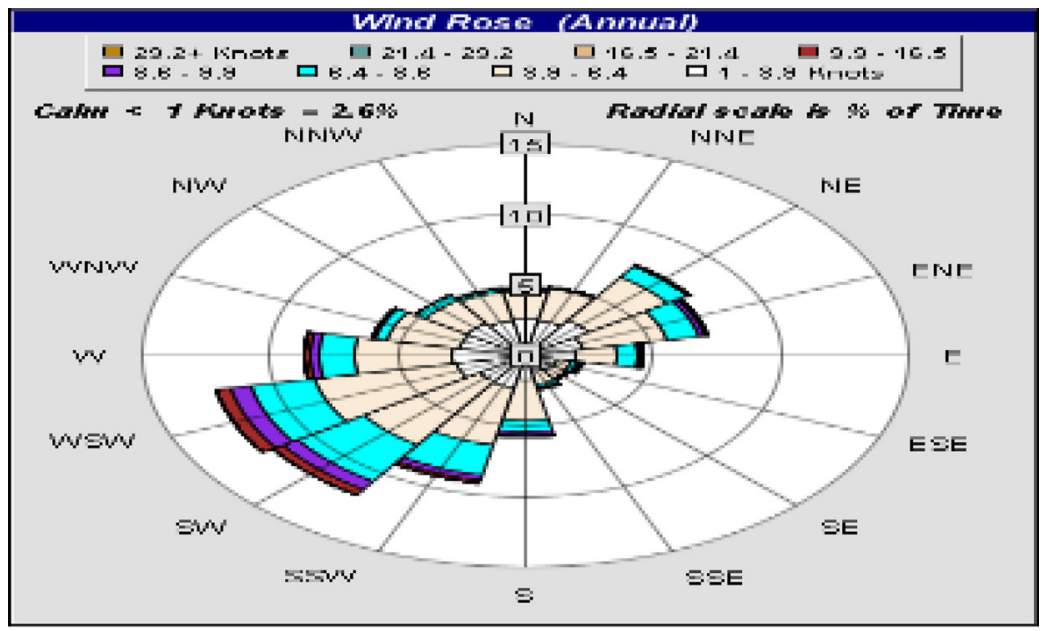

Figure 3. Wind rose diagram (annual) for metro rail station box of Ahmedabad

The wind diagram as shown in Figure 3 demonstrates the wind speed in knots and wind direction at a particular location over a period of time. Typically, the wind direction data is sorted into 12 equal arc segments, $30^{\circ}$ in each segment, in preparation for plotting a circular graph in, which the radius of each of the 12 segments represents the percentage of time that the wind blew from each of the $1230^{\circ}$ direction segments. The wind rose diagram (as shown in Figure 3) shows that during this period, the wind blew from west-south-west and south-west $10 \%$ to $15 \%$ of the time and north-east and east-north-east $5 \%$ to $10 \%$ of the time. 
Total Sky Cover Frequency Distribution (Annual)

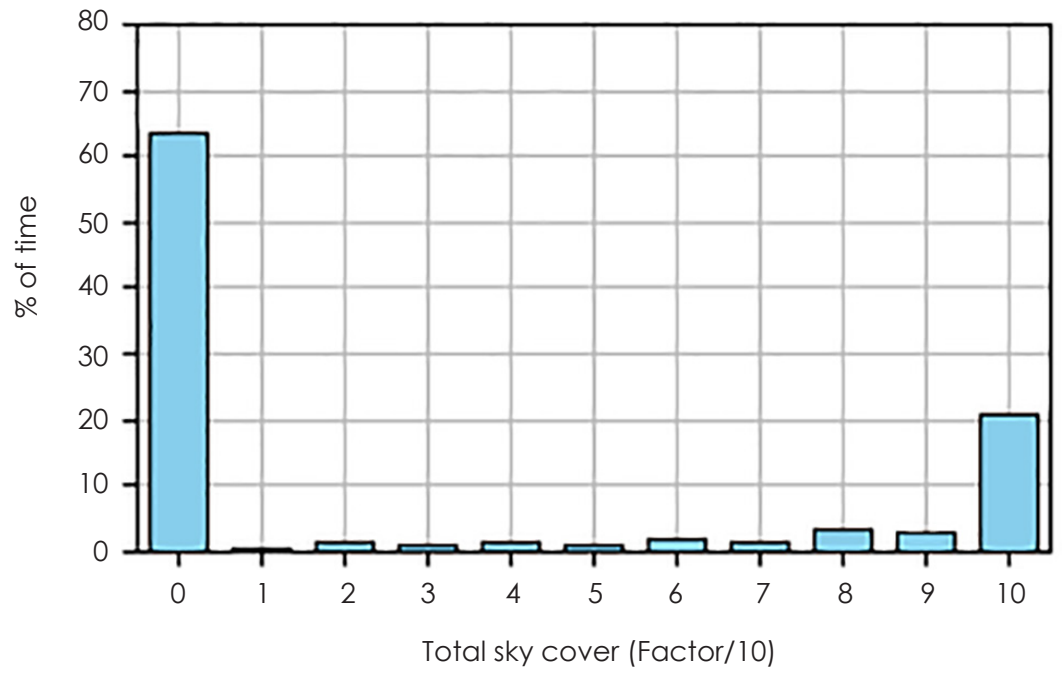

Figure 4. Annual sky cover with respect to percentage of the time for metro rail station box of Ahmedabad

The bar chart as displayed in Figure 4 shows the amount of time (in \%) the total sky is enclosed with full or partial sunlight cover. The total sky cover factor ranges from 0 to 10, denoting maximum daylight at 0 and minimum at 10 . In Figure 4 , it can be clearly seen that $60 \%$ of time, which is the highest \% of time, the sky is exposed to 0 sky factor. Furthermore, the 10 sky-factor is the second highest for $20 \%$ of time. To recapitulate, the sky over the location has a clear unobstructed view without the obstruction of clouds most of the time.

Figure 5 shows the annual dew point distribution frequency with respect to temperature. Here, the $\mathrm{X}$-axis represents the temperature starting from $-2.5^{\circ} \mathrm{C}$ to a maximum of $27.5^{\circ} \mathrm{C}$ at intervals of $2.5^{\circ} \mathrm{C}$. Here, the $Y$-axis represents the percentage of time dew is present at a particular temperature. It gives an idea of the dew falling at a certain temperature. Most of the dew occurs between $22.5^{\circ} \mathrm{C}$ and $25^{\circ} \mathrm{C}$ and the minimum is at $0^{\circ} \mathrm{C}$. To conclude, the bar chart las shown in Figure 5) shows the fluctuating trend of dew points at the location.

The bar chart given in Figure 6 is the histogram representing wind speed classes and the frequency of h/year that are expected for each wind speed class. It illustrates the wind speed frequency distribution with respect to the total time. Here, the $X$-axis represents the wind speed starting from $0 \mathrm{~m} / \mathrm{s}$ to a maximum of $10 \mathrm{~m} / \mathrm{s}$ at an interval of $1 \mathrm{~m} / \mathrm{s}$. The $Y$-axis represents the percentage of time a particular wind speed blows annually. It gives an idea of the maximum wind speed that would affect the location. A wind speed of $2 \mathrm{~m} / \mathrm{s}$ to $3 \mathrm{~m} / \mathrm{s}$ occurs most of the time, which is around $40 \%$. Further, the lowest wind speed affecting the location is $10 \mathrm{~m} / \mathrm{s}$. 


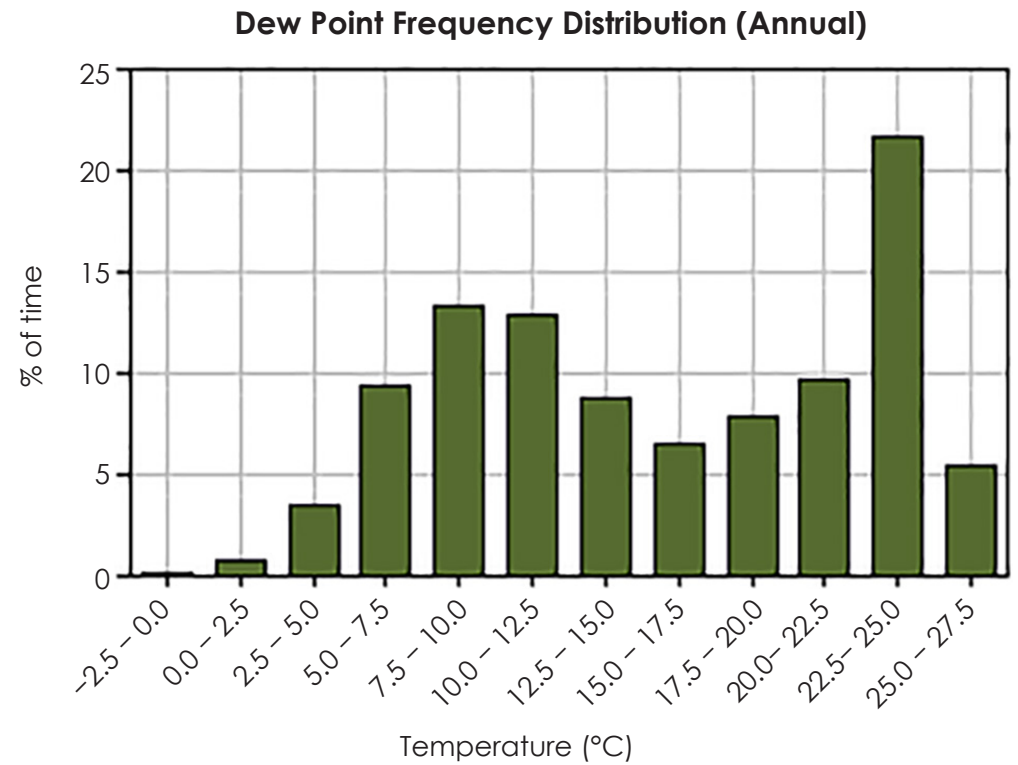

Figure 5. Annual dew point with respect to percentage of time for metro rail station box of Ahmedabad

Wind Speed Frequency Distribution (Annual)

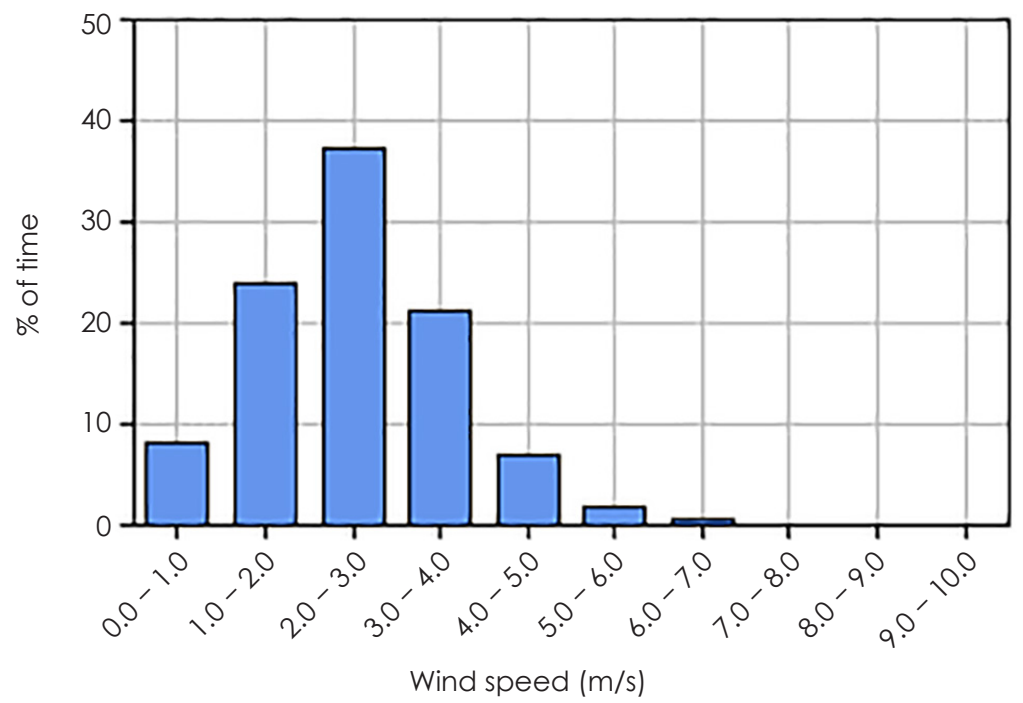

Figure 6. Annual wind speed distribution with respect to percentage of the time for metro rail station box of Ahmedabad 
From the Figure 7, considering all months, it can be seen that the energy used throughout the year to keep the building's temperature at $27^{\circ} \mathrm{C}$ using these materials was $29,690 \mathrm{kWh}$. As shown in Figure 7, there is only a cooling load for all the months of a year due to the location of the building in Ahmedabad, India, which is a very hot and dry area. This indicates that there is only a cooling load for the building. As can be seen, the highest amount of energy consumption occurs in May, June and July. On the other hand, energy consumption in January and February is the lowest, at about 2,190 and 2,280 kWh/day, respectively. All of these analyses are based on a strong database in Green Building Studio analysis software in which the weather specifications of all regions around the world have been established.

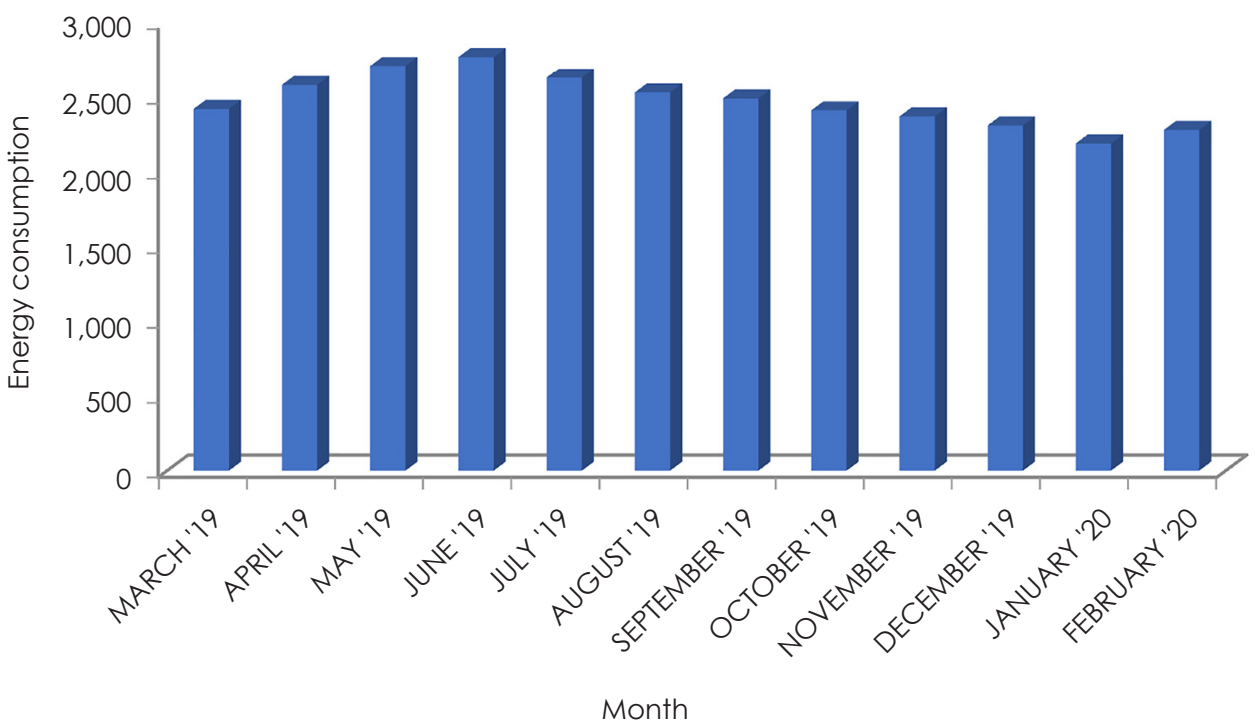

Figure 7. Monthly energy consumption for cooling load kWh/day for metro rail station box of Ahmedabad

\section{Sustainable material selection through FCM}

FCM is a MCDM technique which can be effectively used for the selection of sustainable and green materials for the designing of energy efficient metro rail station box. Firstly, critical parameters governing the energy and efficiency of the materials are identified and evaluated for the metro rail station box. Each parameter is given a code (A, B, C...) for identification. Table 4 represents the list of the identified parameters which would help in the evaluation and selection of the most feasible sustainable material. 
Table 4. Parameters governing the selection of sustainable materials for design of metro rail station box

\begin{tabular}{clc}
\hline No. & Parameters & Code \\
\hline 1 & Thermal insulation & $\mathrm{A}$ \\
2 & Expected life span & $\mathrm{B}$ \\
3 & Expected maintenance & $\mathrm{C}$ \\
4 & Embodied energy & $\mathrm{D}$ \\
5 & Natural day lighting & $\mathrm{E}$ \\
6 & Natural ventilation & $\mathrm{F}$ \\
7 & Carbon emissions & $\mathrm{G}$ \\
8 & Thermal transmittance & $\mathrm{H}$ \\
9 & Microclimate & $\mathrm{I}$ \\
10 & Cost effectiveness & $\mathrm{J}$ \\
11 & Safety & $\mathrm{K}$ \\
12 & Aesthetics & $\mathrm{L}$ \\
\hline
\end{tabular}

The next step is the development of the factored matrix, where each factor is compared with the other factor in a paired comparison manner to find out their relative weights. A 3-point scale has been used where if there is a "Major difference" between two parameters then 3 points need to be considered. If there is "Medium difference", "Minor difference" and "No difference", then 2 points, 1 point and 0 point will be considered, respectively. Thermal insulation (A) is compared with expected life span (B) to identify which parameter has more impact on the sustainable material selection and it has been observed that parameter (A) has to be given priority over parameter (B) with "Medium difference". Thereby, the score has been given as "A2". Similarly, (A) is compared with all the other parameters (C), (D), (E)...(L). Then parameter (B) is compared with (C), (D)...(L). Similar computation is also carried out for all the other parameters. Then the scores of each parameter like score of $(A)$ is obtained by adding the score in each cell like $2+2+0+1+3+3=11$. Similar methodology is followed for all the parameters to obtain the individual scores of all the parameters. The factored matrix is given in Table 5. 
Table 5. Factored matrix of the parameters for selection of sustainable materials for design of metro rail station box

\begin{tabular}{|c|c|c|c|c|c|c|c|c|c|c|c|c|c|}
\hline & B & C & D & $E$ & $\mathbf{F}$ & $\mathbf{G}$ & H & I & $\mathrm{J}$ & K & L & Total & Rank \\
\hline \multirow[t]{12}{*}{ A } & $\mathrm{A} 2$ & A2 & D3 & $\mathrm{AO}$ & $\mathrm{Al}$ & G2 & A3 & 12 & $\mathrm{~J} 2$ & $\mathrm{~K} 1$ & A3 & 11 & 7 \\
\hline & B & BO & B3 & E2 & F3 & G3 & B3 & B2 & B3 & B3 & B2 & 13 & 5 \\
\hline & & C & $\mathrm{Cl}$ & E2 & F3 & G2 & C3 & $\mathrm{Cl}$ & $\mathrm{J} 1$ & K2 & C2 & 7 & 9 \\
\hline & & & D & D2 & D2 & D3 & D3 & D3 & D3 & K3 & D3 & 22 & 1 \\
\hline & & & & $E$ & E2 & G2 & E2 & EO & J2 & $\mathrm{K} 1$ & E2 & 10 & 8 \\
\hline & & & & & $\mathbf{F}$ & G2 & F3 & FO & $\mathrm{J} 2$ & K2 & F3 & 12 & 6 \\
\hline & & & & & & G & G2 & 13 & J3 & K3 & G3 & 16 & 3 \\
\hline & & & & & & & H & $\mathrm{HO}$ & J3 & K3 & L3 & 0 & 12 \\
\hline & & & & & & & & I & $\mathrm{J} 2$ & K2 & L3 & 5 & 11 \\
\hline & & & & & & & & & $\mathrm{J}$ & $\mathrm{K} 1$ & JO & 15 & 4 \\
\hline & & & & & & & & & & K & K3 & 18 & 2 \\
\hline & & & & & & & & & & & L & 6 & 7 \\
\hline
\end{tabular}

The next step is the development of the decision matrix where the appropriate sustainable materials and associated sustainable technologies are compared to arrive to a decision to find out the most feasible option for the design of the metro rail station box. A 5-point scale has been used to develop the decision matrix where if the parameter $(A) \ldots(L)$ is very much suitable and "Excellent" for the available sustainable technology for design of the wall/floor/ ceiling/external cladding of the metro rail station box, then the point has to be considered is 5. Similarly, if the ratings are "Very good", "Good", "Fair" and "Poor", then the points considered are 4, 3, 2 and 1, respectively. Decision matrix has been developed for sustainable materials and technology for floors, walls, ceiling, openings and fenestrations, facade and external finishes for the metro rail station box under design. 
Table 6. Decision matrix for selection of sustainable materials and technology for floors of metro rail station box

\begin{tabular}{|c|c|c|c|c|c|c|c|c|c|c|c|c|c|c|}
\hline $\begin{array}{l}\text { Parameter } \\
\text { Score }\end{array}$ & $\begin{array}{c}\text { A } \\
11\end{array}$ & $\begin{array}{c}B \\
13\end{array}$ & $\begin{array}{l}C \\
7\end{array}$ & $\begin{array}{c}D \\
22\end{array}$ & $\begin{array}{c}E \\
10\end{array}$ & $\begin{array}{c}F \\
12\end{array}$ & $\begin{array}{c}G \\
16\end{array}$ & $\begin{array}{l}\mathrm{H} \\
\mathbf{0}\end{array}$ & $\begin{array}{l}1 \\
5\end{array}$ & $\begin{array}{c}J \\
15\end{array}$ & $\begin{array}{c}K \\
18\end{array}$ & $\begin{array}{l}L \\
6\end{array}$ & $\begin{array}{l}\text { Total } \\
\text { Score }\end{array}$ & Rank \\
\hline \multicolumn{15}{|l|}{$\begin{array}{l}\text { Available } \\
\text { Technology }\end{array}$} \\
\hline $\begin{array}{l}\text { Cement } \\
\text { concrete } \\
\text { floor }\end{array}$ & $\begin{array}{c}1 \\
11\end{array}$ & $\begin{array}{c}4 \\
52\end{array}$ & $\begin{array}{c}3 \\
21\end{array}$ & $\begin{array}{c}1 \\
22\end{array}$ & $\begin{array}{c}2 \\
20\end{array}$ & $\begin{array}{c}2 \\
24\end{array}$ & $\begin{array}{c}1 \\
16\end{array}$ & $\begin{array}{l}2 \\
0\end{array}$ & $\begin{array}{c}3 \\
15\end{array}$ & $\begin{array}{c}4 \\
60\end{array}$ & $\begin{array}{c}3 \\
54\end{array}$ & $\begin{array}{l}1 \\
6\end{array}$ & 301 & 5 \\
\hline $\begin{array}{l}\text { Anti-skid } \\
\text { vitrified tiles }\end{array}$ & $\begin{array}{c}2 \\
22\end{array}$ & $\begin{array}{c}4 \\
52\end{array}$ & $\begin{array}{c}4 \\
28\end{array}$ & $\begin{array}{c}1 \\
22\end{array}$ & $\begin{array}{c}4 \\
40\end{array}$ & $\begin{array}{c}4 \\
36\end{array}$ & $\begin{array}{c}1 \\
16\end{array}$ & $\begin{array}{l}4 \\
0\end{array}$ & $\begin{array}{c}4 \\
20\end{array}$ & $\begin{array}{c}3 \\
45\end{array}$ & $\begin{array}{c}3 \\
54\end{array}$ & $\begin{array}{c}4 \\
24\end{array}$ & 359 & 3 \\
\hline $\begin{array}{l}\text { Honed } \\
\text { granite floor }\end{array}$ & $\begin{array}{c}2 \\
22\end{array}$ & $\begin{array}{c}4 \\
52\end{array}$ & $\begin{array}{c}4 \\
28\end{array}$ & $\begin{array}{c}1 \\
22\end{array}$ & $\begin{array}{c}3 \\
30\end{array}$ & $\begin{array}{c}4 \\
36\end{array}$ & $\begin{array}{c}2 \\
32\end{array}$ & $\begin{array}{l}4 \\
0\end{array}$ & $\begin{array}{c}4 \\
20\end{array}$ & $\begin{array}{c}1 \\
15\end{array}$ & $\begin{array}{c}3 \\
54\end{array}$ & $\begin{array}{c}4 \\
24\end{array}$ & 335 & 4 \\
\hline $\begin{array}{l}\text { Stone floor } \\
\text { tiles }\end{array}$ & $\begin{array}{c}3 \\
33\end{array}$ & $\begin{array}{c}4 \\
52\end{array}$ & $\begin{array}{c}4 \\
28\end{array}$ & $\begin{array}{c}4 \\
88\end{array}$ & $\begin{array}{c}3 \\
30\end{array}$ & $\begin{array}{c}4 \\
36\end{array}$ & $\begin{array}{c}4 \\
64\end{array}$ & $\begin{array}{l}3 \\
0\end{array}$ & $\begin{array}{c}4 \\
20\end{array}$ & $\begin{array}{c}4 \\
60\end{array}$ & $\begin{array}{c}4 \\
72\end{array}$ & $\begin{array}{c}2 \\
12\end{array}$ & 495 & 2 \\
\hline $\begin{array}{l}\text { Polished } \\
\text { Kota-stone }\end{array}$ & $\begin{array}{c}3 \\
33\end{array}$ & $\begin{array}{c}4 \\
52\end{array}$ & $\begin{array}{c}4 \\
28\end{array}$ & $\begin{array}{c}4 \\
88\end{array}$ & $\begin{array}{c}4 \\
40\end{array}$ & $\begin{array}{c}3 \\
36\end{array}$ & $\begin{array}{c}4 \\
64\end{array}$ & $\begin{array}{l}4 \\
0\end{array}$ & $\begin{array}{c}4 \\
20\end{array}$ & $\begin{array}{c}4 \\
60\end{array}$ & $\begin{array}{c}4 \\
72\end{array}$ & $\begin{array}{c}3 \\
18\end{array}$ & 511 & 1 \\
\hline
\end{tabular}

From the decision matrix, as given in Table 6, the parameter scores in the columns are compared with the available technologies for the design of the floor of the metro rail station box. For the option of polished Kota-stone flooring, when parameter A (thermal insulation) is compared that to what extent polished Kota-stone flooring is capable for providing thermal insulation, it has been observed that the rating of "Good" can be given. Thus, a score of 3 has been granted. For parameter B (expected life span), it has been observed that polished Kota-stone flooring may be given a rating of "Very good" and thus granted a score of 4. Likewise, all the parameters from (A)...(L) are compared with the performance of the technology under consideration. Finally, for the polished Kota-stone flooring, the scores are computed like $11 * 3+13 * 4+7 * 4+22 * 4+10 * 4$ $+12 * 4+16 * 4+0 * 4+5 * 4+15 * 4+18 * 4+6 * 3=511$. Similarly, the scores of other options like cement concrete flooring, anti-skid vitrified tiles, honed granite floor and stone-floor-tiles are 301, 359, 335 and 495, respectively. Thereby, polished Kota-stone flooring appears to be the most feasible sustainable material with maximum score of 511 followed by stone-floor-tiles, anti-skid vitrified tiles, honed granite floor and cement concrete floor.

According to the decision matrix given in Table 7, the stone-floor-tile cladding appear to be the most feasible material followed by the polished Kota-stone cladding, ferro-cement wall panel, vitrified tiles, granite cladding and plaster with acrylic emulsion. 
Table 7. Decision matrix for selection of sustainable materials and technology for walls of metro rail station box

\begin{tabular}{lcccccccccccccc}
\hline Parameter & $\mathbf{A}$ & $\mathbf{B}$ & $\mathbf{C}$ & $\mathbf{D}$ & $\mathbf{E}$ & $\mathbf{F}$ & $\mathbf{G}$ & $\mathbf{H}$ & $\mathbf{I}$ & $\mathbf{J}$ & $\mathbf{K}$ & $\mathbf{L}$ & \multirow{2}{*}{ Total } & Rank \\
Score & $\mathbf{1 1}$ & $\mathbf{1 3}$ & $\mathbf{7}$ & $\mathbf{2 2}$ & $\mathbf{1 0}$ & $\mathbf{1 2}$ & $\mathbf{1 6}$ & $\mathbf{0}$ & $\mathbf{5}$ & $\mathbf{1 5}$ & $\mathbf{1 8}$ & $\mathbf{6}$ & & \\
\hline Available & & & & & & & & & & & & & & \\
Technology & & & & & & & & & & & & & & \\
Granite & 2 & 4 & 4 & 1 & 4 & 3 & 1 & 3 & 3 & 1 & 4 & 5 & 348 & 5 \\
cladding & 22 & 52 & 28 & 22 & 40 & 36 & 16 & 0 & 15 & 15 & 72 & 30 & & \\
Vitrified tiles & 2 & 4 & 3 & 2 & 4 & 4 & 2 & 3 & 3 & 2 & 4 & 5 & 406 & 4 \\
& 22 & 52 & 21 & 44 & 40 & 48 & 32 & 0 & 15 & 30 & 72 & 30 & & \\
Plaster with & 2 & 4 & 3 & 1 & 4 & 4 & 1 & 3 & 3 & 2 & 3 & 4 & 344 & 6 \\
acrylic emulsion & 22 & 52 & 21 & 22 & 40 & 48 & 16 & 0 & 15 & 30 & 54 & 24 & & \\
Polished Kota- & 2 & 5 & 5 & 4 & 4 & 4 & 4 & 3 & 5 & 4 & 4 & 3 & 537 & 2 \\
stone cladding & 22 & 65 & 35 & 88 & 40 & 48 & 64 & 0 & 25 & 60 & 72 & 18 & & \\
Stone-floor- & 2 & 5 & 5 & 4 & 4 & 4 & 4 & 2 & 5 & 4 & 5 & 3 & 555 & 1 \\
tile cladding & 22 & 65 & 35 & 88 & 40 & 48 & 64 & 0 & 25 & 60 & 90 & 18 & & \\
Ferro-cement & 3 & 4 & 4 & 4 & 4 & 4 & 3 & 2 & 4 & 4 & 4 & 3 & 507 & 3 \\
wall panel & 33 & 52 & 28 & 88 & 40 & 48 & 48 & 0 & 20 & 60 & 72 & 18 & & \\
\hline
\end{tabular}

According to the decision matrix given in Table 8 for the design of ceiling of the metro rail station box toughened fibre-glass appear to be the most feasible sustainable material followed by ferro-cement roof panel, perforated metal ceiling and plaster with acrylic emulsion.

According to the decision matrix given in Table 9, the insulated fibre-glass door appear to be the most feasible sustainable material for openings and fenestrations followed by fire rated MS door with vision panel, partially glazed door, MS rolling shutter and normal wooden door.

Table 8. Decision matrix for selection of sustainable materials and technology for ceiling of metro rail station box

\begin{tabular}{lcccccccccccccc}
\hline Parameter & A & B & C & D & E & F & G & H & I & J & K & L & \multirow{2}{*}{ Total } & Rank \\
Score & $\mathbf{1 1}$ & $\mathbf{1 3}$ & $\mathbf{7}$ & $\mathbf{2 2}$ & $\mathbf{1 0}$ & $\mathbf{1 2}$ & $\mathbf{1 6}$ & $\mathbf{0}$ & $\mathbf{5}$ & $\mathbf{1 5}$ & $\mathbf{1 8}$ & $\mathbf{6}$ & & \\
\hline Available & & & & & & & & & & & & & & \\
Technology & & & & & & & & & & & & & & \\
Perforated & 1 & 4 & 3 & 2 & 3 & 3 & 2 & 2 & 3 & 2 & 4 & 3 & 361 & 3 \\
metal ceiling & 11 & 52 & 21 & 44 & 30 & 36 & 32 & 0 & 15 & 30 & 72 & 18 & & \\
Plaster with & 2 & 3 & 3 & 1 & 3 & 3 & 1 & 4 & 3 & 3 & 4 & 4 & 342 & 4 \\
acrylic & 22 & 39 & 21 & 22 & 30 & 36 & 16 & 0 & 15 & 45 & 72 & 24 & & \\
emulsion & & & & & & & & & & & & & & \\
Toughened & 4 & 4 & 4 & 5 & 4 & 3 & 3 & 3 & 5 & 3 & 3 & 4 & 506 & 1 \\
fibre-glass & 44 & 52 & 28 & 110 & 40 & 36 & 48 & 0 & 25 & 45 & 54 & 24 & & \\
Ferro-cement & 3 & 4 & 4 & 4 & 4 & 3 & 4 & 3 & 4 & 3 & 4 & 3 & 496 & 2 \\
roof panel & 33 & 52 & 28 & 88 & 40 & 36 & 64 & 0 & 20 & 45 & 72 & 18 & & \\
\hline
\end{tabular}


Table 9. Decision matrix for selection of sustainable materials and technology for openings and fenestrations of metro rail station box

\begin{tabular}{lcccccccccccccc}
\hline Parameter & $\mathbf{A}$ & $\mathbf{B}$ & $\mathbf{C}$ & $\mathbf{D}$ & $\mathbf{E}$ & $\mathbf{F}$ & $\mathbf{G}$ & $\mathbf{H}$ & $\mathbf{I}$ & $\mathbf{J}$ & $\mathbf{K}$ & $\mathbf{L}$ & \multirow{2}{*}{ Total } & Rank \\
Score & $\mathbf{1 1}$ & $\mathbf{1 3}$ & $\mathbf{7}$ & $\mathbf{2 2}$ & $\mathbf{1 0}$ & $\mathbf{1 2}$ & $\mathbf{1 6}$ & $\mathbf{0}$ & $\mathbf{5}$ & $\mathbf{1 5}$ & $\mathbf{1 8}$ & $\mathbf{6}$ & & \\
\hline Available & & & & & & & & & & & & & & \\
Technology & & & & & & & & & & & & & & \\
MS rolling & 1 & 4 & 3 & 2 & 1 & 2 & 2 & 2 & 3 & 2 & 5 & 2 & 341 & 4 \\
shutter & 11 & 52 & 21 & 44 & 10 & 24 & 32 & 0 & 15 & 30 & 90 & 12 & & \\
Fire rated & 5 & 4 & 3 & 2 & 3 & 2 & 2 & 3 & 3 & 2 & 5 & 2 & 405 & 2 \\
$\begin{array}{l}\text { MS door with } \\
\text { vision panel }\end{array}$ & 55 & 52 & 21 & 44 & 30 & 24 & 32 & 0 & 15 & 30 & 90 & 12 & & \\
Partially & 2 & 3 & 3 & 2 & 4 & 2 & 3 & 2 & 3 & 3 & 3 & 3 & 350 & 3 \\
glazed door & 22 & 39 & 21 & 44 & 40 & 24 & 48 & 0 & 15 & 45 & 54 & 18 & & \\
Normal & 1 & 3 & 2 & 2 & 2 & 2 & 2 & 2 & 2 & 4 & 3 & 3 & 326 & 5 \\
wooden door & 11 & 39 & 14 & 44 & 20 & 24 & 32 & 0 & 10 & 60 & 54 & 18 & & \\
Insulated fibre- & 3 & 5 & 4 & 4 & 4 & 2 & 4 & 3 & 4 & 3 & 4 & 4 & 503 & 1 \\
glass door & 33 & 65 & 28 & 88 & 40 & 24 & 64 & 0 & 20 & 45 & 72 & 24 & & \\
\hline
\end{tabular}

\section{RESULTS AND DISCUSSIONS}

Details of the building materials for the primary building components such as the floor, walls and ceiling for construction of the elevated corridor metro rail station box are presented in Table 10.

Table 10. Details of building materials for building components of the elevated metro rail station

\section{Name of Building Component} in the Various Rooms

\begin{tabular}{ll}
\hline Floor & $\begin{array}{l}\text { Cement concrete floor } \\
\text { Anti-skid vitrified tiles } \\
\text { Honed granite floor }\end{array}$ \\
Wall & $\begin{array}{l}\text { Granite cladding } \\
\text { Vitrified tiles } \\
\text { Plaster with acrylic emulsion paint } \\
\text { Ceiling }\end{array}$ \\
& Perforated metal ceiling \\
& Plaster with acrylic emulsion paint \\
\hline
\end{tabular}

The energy consumption was determined based on the baseline design, including the existing material specifications of the building. Then, alternative materials were used to replace the baseline design to investigate their impact on reducing and/or increasing energy consumption. Finally, a set of higherperformance materials was also recommended for the purpose of reducing the energy consumption of the building, which would lead to reduction of embodied energy and carbon dioxide emissions. Therefore, all these existing 
materials, which are utilised in the construction of the elevated metro rail station box, were considered as baseline materials based on which alternative materials were analysed and recommended to improve energy building performance throughout the entire project life cycle. The embodied energy of the existing and proposed alternative materials for the floor, wall and ceiling modification were calculated from National Building Code of India 2016 (Bureau of Indian Standards, 2016), India Construction Materials Database of Embodied Energy and Global Warming Potential Methodology Report (IFC [International Finance Corporation], 2017), Annexure 57 of the Guidelines for Designers and Consultants: Part 1 (Lutzkendorf and Balouktsi, 2016), Praseeda, Reddy and Mani (2015) and Reddy and Jagadish (2003). The overall modifications of the floor, walls and ceiling of the proposed metro rail station box for achieving maximum energy savings and sustainable design has been considered according to Energy Conservation Building Code 2017 and National Building Code of India 2016. As the study is carried out in the western region of India, this database would be suitable. Limitations of the embodied energy data base for Indian context are that no Indian Standard (IS) code is available for the estimation of embodied energy in India. Furthermore, Indian Construction Materials Database has been prepared in consultation of targeted key stakeholders of Indian construction sector and thereby largely depends on the opinion given by the consultants. The database only covers 36 "priority materials" and some key alternatives to commonly used materials in major sectors. As far as possible, data on Indian production process have been used to ensure technological and geographical representativeness. Where this data has not been possible due to lack of India-specific data sources, the data for European production process have been used with input materials and fuels adjusted to reflect Indian production. In these cases, the possible technological differences have been assessed and discussed with stakeholders of India to ensure that the data for these materials remain representative and reliable.

According to IFC (2017), the embodied energy of a material needs to be computed for its entire life cycle. The equation for computation of total embodied energy as recommended by India Construction Materials Database (IFC, 2017) is given the following equation:

$$
\begin{array}{ll}
\text { Total Embodied } & \sum_{i=1}^{n} E p+\sum_{i=1}^{n} E t+\sum_{i=1}^{n} E C+\sum_{i=1}^{n} E m \\
& +\sum_{i=1}^{n} E d-\sum_{i=1}^{n} E r
\end{array}
$$

Where $i=$ number of material for which the embodied energy is computed; $n=$ the number of cycles considered for the computation; $E_{p}=$ energy used in product processing; $E_{\dagger}=$ energy used in transportation of the material; $E_{c}=$ energy used in construction; $E_{m}=$ energy used in maintenance; $E_{d}=$ energy used in demolition, deconstruction and disposal and $E_{r}=$ energy for reuse or recycle potential. 
As a sample calculation, the embodied energy of the existing floor material like cement concrete floor can be computed through Equation 1. For one material, i.e., $i=1$ and for $n=1$ (considering each of the components of TEE undergoes a single cycle), for $E_{p}=0.09 ; E_{t}=0.93 ; E_{c}=0.20 ; E_{m}=0.05 ; E_{d}=0.05$ and $E_{r}=0.02$ (India Construction Materials Database [IFC, 2017] for cement concrete floor)

TEE for cement concrete floor $=0.09+0.93+0.20+0.05+0.05-0.02=$ $1.3 \mathrm{MJ} / \mathrm{m}^{2}$. This value of embodied energy is considered for the selection of alternative materials for floor of the proposed metro rail station box.

\section{Floor Modification}

In this study, two alternative components are contemplated for the floor, i.e., anti-skid vitrified tiles and honed granite floor. So, the stone-floor-tile and polished Kota-stone were replaced by these types of materials to investigate their ability to reduce energy consumption. The cement concrete flooring was kept unchanged. As shown in Table 11, there was about $7 \mathrm{MJ} / \mathrm{m}^{2}$ to $8 \mathrm{MJ} / \mathrm{m}^{2}$ difference between the baseline floor and the two alternative floors observed.

Table 11. Proposed alternatives for floor of metro rail station box

\begin{tabular}{|c|c|c|c|c|c|c|}
\hline No. & Existing & $\begin{array}{c}\text { Embodied } \\
\text { Energy } \\
\left(\mathrm{MJ} / \mathrm{m}^{2}\right)\end{array}$ & $\begin{array}{l}\text { Alternate } \\
\text { Materials }\end{array}$ & $\begin{array}{c}\text { Embodied } \\
\text { Energy } \\
\left(\mathrm{MJ} / \mathrm{m}^{2}\right)\end{array}$ & $\begin{array}{c}\text { Embodied } \\
\text { Energy Savings }\end{array}$ & Remark \\
\hline 1 & $\begin{array}{l}\text { Cement } \\
\text { concrete floor }\end{array}$ & 1.3 & Unchanged & 1.3 & $0 \%$ & \\
\hline 2 & $\begin{array}{l}\text { Anti-skid } \\
\text { vitrified tiles }\end{array}$ & 8.2 & $\begin{array}{l}\text { Stone floor } \\
\text { tile }\end{array}$ & 0.44 & $94.63 \%$ & \\
\hline 3 & $\begin{array}{l}\text { Honed granite } \\
\text { floor }\end{array}$ & 13.9 & $\begin{array}{l}\text { Polished } \\
\text { Kota-stone }\end{array}$ & 3.7 & $73.38 \%$ & \\
\hline
\end{tabular}

\section{Wall Modification}

Granite cladding, vitrified tiles, and plaster with acrylic emulsion paint were replaced as the wall component of the building with alternative materials, such as polished Kota-stone cladding, stone-floor-tile, and ferro-cement wall panel respectively to identify a material with better performance while retaining the original structure of the building. Table 10 indicates the amount of energy used annually based on the baseline design and the use of alternative materials as the wall component. Table 12 presents the proposed alternatives for the wall of the metro rail station box. 
Table 12. Proposed alternatives for the wall components of the metro rail station box

\begin{tabular}{|c|c|c|c|c|c|c|}
\hline No. & Existing & $\begin{array}{c}\text { Embodied } \\
\text { Energy } \\
\left(\mathrm{MJ} / \mathrm{m}^{2}\right) \\
\end{array}$ & $\begin{array}{l}\text { Alternate } \\
\text { Materials }\end{array}$ & $\begin{array}{l}\text { Embodied } \\
\text { Energy } \\
\left(\mathrm{MJ} / \mathrm{m}^{2}\right)\end{array}$ & $\begin{array}{l}\text { Embodied } \\
\text { Energy } \\
\text { Savings }\end{array}$ & Remark \\
\hline 1 & $\begin{array}{l}\text { Granite } \\
\text { cladding }\end{array}$ & 13.9 & $\begin{array}{l}\text { Polished } \\
\text { Kota- stone } \\
\text { cladding }\end{array}$ & 3.7 & $73.38 \%$ & $\begin{array}{l}3.6 \text { (Light } \\
\text { weight } \\
\text { concrete } \\
\text { block) }\end{array}$ \\
\hline 2 & Vitrified tiles & $\begin{aligned} & 8.2+3.6 \\
+ & 1.1=12.9\end{aligned}$ & $\begin{array}{l}\text { Stone floor } \\
\text { tile }\end{array}$ & $\begin{aligned} & 0.44+3.6 \\
+ & 1.1=5.14\end{aligned}$ & $60.15 \%$ & $\begin{array}{c}1.1 \text { (Cement } \\
\text { mortar) }\end{array}$ \\
\hline 3 & $\begin{array}{l}\text { Plaster with } \\
\text { acrylic } \\
\text { emulsion paint }\end{array}$ & $\begin{array}{c}61.5+4.8+ \\
3.6=69.9\end{array}$ & $\begin{array}{l}\text { Ferro- } \\
\text { cement wall } \\
\text { panel }\end{array}$ & 2.3 & $96.7 \%$ & $\begin{array}{c}61.5 \text { (Cement } \\
\text { mortar) }\end{array}$ \\
\hline
\end{tabular}

\section{Ceiling Modification}

By using toughened fibre-glass and ferro-cement roof panels in the ceiling, the annual operational energy consumption was reduced by about $306.5 \mathrm{MJ} / \mathrm{m}^{2}$, considerably more than the reductions achieved through other modifications. In a nut shell, considering the temperature necessities in the National Building Code, i.e., $27^{\circ} \mathrm{C}$, wind rose, and temperature diagrams, the orientation of openings can be adjusted to get the maximum benefit of natural air circulation and ventilation. Also, better alternative materials that are translucent are chosen to allow maximum daylight enter the station box leading to a fewer artificial lighting fixtures and lower energy demand. The energy consumed annually is statistically studied and thereby the materials are suggested to be used as alternative baseline material. Table 13 presents the proposed alternative materials for ceiling modifications.

Table 13. Proposed alternatives of the ceiling components of the metro rail station box

\begin{tabular}{ccccccc}
\hline No. & Existing & $\begin{array}{c}\text { Embodied } \\
\text { energy } \\
\left(\mathbf{M J} / \mathbf{m}^{2}\right)\end{array}$ & $\begin{array}{c}\text { Alternate } \\
\text { Ceiling } \\
\text { Materials }\end{array}$ & $\begin{array}{c}\text { Embodied } \\
\text { Energy } \\
\left(\mathbf{M J} / \mathbf{m}^{2}\right)\end{array}$ & $\begin{array}{c}\text { Embodied } \\
\text { Energy } \\
\text { Savings }\end{array}$ & Remark \\
\hline $1 \quad \begin{array}{l}\text { Perforated } \\
\text { metal ceiling }\end{array}$ & 330 & $\begin{array}{c}\text { Toughened } \\
\text { fibre-glass }\end{array}$ & 23.5 & $92.87 \%$ & $\begin{array}{c}3.6 \text { (Light } \\
\text { weight } \\
\text { concrete } \\
\text { block) }\end{array}$ \\
$2 \quad \begin{array}{l}\text { Plaster with } \\
\text { acrylic } \\
\text { emulsion paint }\end{array}$ & $\begin{array}{c}4.8+61.5 \\
+3.6=67.1\end{array}$ & $\begin{array}{c}\text { Ferro-cement } \\
\text { roof panel }\end{array}$ & 2.3 & $96.57 \%$ & $\begin{array}{c}4.8 \text { (Cement } \\
\text { plaster) }\end{array}$ \\
\hline
\end{tabular}




\section{CONCLUSION}

Infrastructure projects consume significant amount of energy leading towards negative impact on the surrounding environment. It also results in resource depletion. The results of the study of the infrastructure facility like the metro rail station box demonstrated the significance in the use of BIM as an alternative option tool to generate energy-efficient design using a sustainable approach. Utilising BIM for wind analysis, sky cover, etc. proves to be an excellent and reliable strategy to decide the location of the openings and its design in various zones to provide maximum possible natural air ventilation and to choose the façade materials properties based on their behaviour and also the solar energy potential of the infrastructure facility.

Energy simulation essentially investigates the building performance virtually in the design phase, which enables stakeholders of the project to decide building specifications that have a minimal effect on the environment. In the AEC industry, BIM is proved to be an effective tool for the designers as they design optimum and best in class building design and orientations. BIM can be considered for energy simulation to measure and improve building performance only in the design phase. By application of FCM, which is a MCDM technique, it has been observed that polished Kota-stone flooring, stone-floor-tile cladding, toughened fibre-glass ceiling and insulated fibre-glass door appear to be the most feasible sustainable material for flooring, wall cladding, ceiling, openings and fenestrations for the design of the metro rail station box of Ahmedabad, India.

Further, this incorporation of BIM in the design phase could be utilised to generate energy-efficient designs and reduce the rework, thus minimizing time and cost overruns. BIM helps to reduce and optimise energy demand and consumption. It may also help prevent any harmful impacts on the environment through the development of energy-efficient and sustainable infrastructure. It has been observed from the study that for the construction of an energyefficient metro rail station box, the alternative floor materials like stone-floortiles having thermal properties like thermal conductivity of $1.4763 \mathrm{~W} /(\mathrm{mK})$ and specific heat of $1.2737 \mathrm{MJ} / \mathrm{m}^{3} \mathrm{~K}$ (Energy Conservation Building Code, 2017) and materials having similar thermal properties as that of stone-floor-tiles can contribute in saving the embodied energy up to $94.63 \%$. Polished Kota-stones having thermal properties like thermal conductivity of $3.0229 \mathrm{~W} /(\mathrm{mK})$ and specific heat of $2.0732 \mathrm{MJ} / \mathrm{m}^{3} \mathrm{~K}$ and materials having similar thermal properties can contribute in embodied energy savings up to $73.38 \%$. Alternative wall components like polished Kota-stone wall cladding having thermal conductivity of $3.0229 \mathrm{~W} /(\mathrm{mK})$, specific heat of $2.0732 \mathrm{MJ} / \mathrm{m}^{3} \mathrm{~K}$ and other materials having similar thermal properties can contribute in saving the embodied energy up to $73.38 \%$. Ferro-cement wall panels having thermal conductivity of $0.3275 \mathrm{~W} /(\mathrm{mK})$ and specific heat of $1.1948 \mathrm{MJ} / \mathrm{m}^{3} \mathrm{~K}$ and materials having similar thermal properties can contribute in savings the embodied energy up to $96.7 \%$. Furthermore, the use of alternative materials in the ceiling like toughened fibre-glass having thermal conductivity of $0.2252 \mathrm{~W} /(\mathrm{mK})$ and specific heat of $1.693 \mathrm{MJ} / \mathrm{m}^{3} \mathrm{~K}$ and materials having similar thermal properties can contribute to save embodied energy up to $92.87 \%$. Finally, ferrocement roof panels having thermal conductivity of $0.3275 \mathrm{~W} /(\mathrm{mK})$ and specific heat of $1.1948 \mathrm{MJ} / \mathrm{m}^{3} \mathrm{~K}$ and materials having similar thermal properties can contribute to save embodied energy up to $96.57 \%$. Hence, BIM technology may be recommended as an 
effective alternative tool which can be incorporated by the project stakeholders to arrive at the effective solutions to reduce operational and embodied energy consumption. The limitation of the present research work is that it is does not use any physics based quantification method or mathematical optimisation tool for the material selection. The study focuses only on the usage of MCDM tool like FCM methodology, which is a simple but quick method, for decision making. The results obtained can be feasible solutions and taken forward for further improvements.

\section{SCOPE FOR FUTURE RESEARCH}

This research work can be extended by integrating applications of Internet of things (loT) with the features of BIM, which will lead to an automated control and monitoring plan to develop energy efficient infrastructure. This can be achieved by integrating the sensor data with the proposed BIM model to make automated real time decisions to control the entire heating-cooling system and also all the lighting fixtures based on the standard requirements. As the concept is generic, this model can be extended to other building facilities including shopping malls, multiplexes and other commercial establishments.

\section{ACKNOWLEDGEMENTS}

The authors would like to thank Pandit Deendayal Petroleum University (PDPU), India and all concerned transportation authorities for providing the necessary facilities to carry out this investigation.

\section{REFERENCES}

Adewunmi, Y.A., Alister, A. and Thabethe, B.P. (2019). Energy efficiency practices in facilities management in Johannesburg. Journal of Facilities Management, 17(4): 331-343. https://doi.org/10.1108/JFM-11-2018-0067.

Al Ka'bi, A.H. (2020). Comparison of energy simulation applications used in green building. Annals of Telecommunication, 75: 271-290. https://doi.org/10 .1007/s 12243-020-00771-6.

Alwan, Z. and Jones, P. (2014). The importance of embodied energy in carbon footprint assessment. Structural Survey, 32(1): 49-60. https://doi.org/10 $.1108 /$ SS-01-2013-0012.

Ayarkwa, J., Adinyira, E., Koranteng, C. and Addy, M.N. (2014). Architect's perception on the challenges of building energy efficiency in Ghana. Structural Survey, 32(4): 365-376. https://doi.org/10.1108/SS-03-2014-0014.

Azhar, S. and Brown, J. (2009). BIM for sustainability analysis. International Journal of Construction Education and Research, 5(4): 276-292. https://doi.org/ 10.1080/15578770903355657. 
Bapat, H. and Sarkar, D. (2019). 6D energy efficient metro rail station design using BIM: A review of literature. In F. Hidoussi (ed.), Proceedings of International Conference on Innovative Applied Energy. Oxford: IAPE'19, Article 274 (ID: 809).

Bureau of Indian Standards (2016). National Building Code of India 2016: Approach to Sustainability. Vol. 2, Part 11. Old Delhi, India: Bureau of Indian Standards.

Catalina, T., Virgone, J. and Blanco, E. (2008). Development and validation of regression models to predict monthly heating demand for residential buildings. Energy and Building, 40(10): 1825-1832. https://doi.org/10.1016/j. enbuild.2008.04.001.

Chong, H., Chong, Y., Fan, S.L., Sutrisna, M. and Shang, H.H. (2017). Preliminary contractual framework for BIM-enabled projects. Journal of Construction Engineering and Management, 143(7): 1-8. https://doi.org/10.1061/(ASCE) CO.1943-7862.0001278.

Crawley, D.B., Hand, J.W., Kummert, M. and Griffith, B.T. (2005). Contrasting the capabilities of building energy performance simulation programs. In Building Simulation: Ninth International IBPSA Conference. Montreal: International Building Performance Simulation Association (IBPSA), 231-238. Available at: http://www.ibpsa.org/proceedings/bs2005/bs05_0231_238.pdf.

Das, B. and Garcia-Diaz, A. (2001). Factor selection guidelines for job evaluation: A computerized statistical procedure. Computers and Industrial Engineering, 40: 259-272. https://doi.org/10.1016/S0360-8352(01)00028-6.

Ekici, B.B. and Aksoy, T. (2009). Prediction of building energy consumption by using artificial neural network. Advances in Engineering Software, 40(5): 356-362. https://doi.org/10.1016/j.advengsoft.2008.05.003.

Energy Conservation Building Code (2017). New Delhi: Ministry of Power, Government of India.

Hammond, G.P. and Jones, C.I. (2008). Embodied energy and carbon in construction materials. Energy, 161(2): 87-98. https://doi.org/10.1680/ener .2008.161.2.87.

Hernandez, P. and Kenny, P. (2008). Defining zero energy buildings: A life cycle perspective. In PLEA 2008: 25th Conference on Passive and Low Energy Architecture, Dublin, 22nd to 24th October 2008. Dublin: University College Dublin.

IFC (International Finance Corporation) (2017). India Construction Materials Database of Embodied Energy and Global Warming Potential Methodology Report. Washington DC: IFC, World Bank Group.

Jelle, B.P., Gustavsen, A. and Baetens, R. (2010). The high performance thermal building insulation materials and solutions of tomorrow. In Thermal Performance of the Exterior Envelopes of Whole Buildings XI Conference Proceedings. Atlanta, GA: American Society of Heating, Refrigerating and Air-Conditioning Engineers (ASHRAE).

Kahya, E. (2018). A wage model consisted of job evaluation, employee characteristics and job performance. Pamukkale University Journal of Engineering Sciences, 24(4): 720-729. https://doi.org/10.5505/pajes.2017.92609. 
Khanzadi, M., Sheikhkhoshkar, M. and Banihashemi, S. (2020). BIM applications toward key performance indicators of construction projects in Iran. International Journal of Construction Management, 20(4): 305-320. https://doi.org/10.1080/15623599.2018.1484852.

Khasreen, M., Phillip, F.G.B. and Menzies, G. (2009). Life-cycle assessment and the environmental impact of buildings: A review. Sustainability, 1(3): 674-701. https://doi.org/10.3390/su1030674.

Laine, T., Hänninen, R. and Karola, A. (2007). Benefits of BIM in the thermal performance management. In Proceedings: Building Simulation 2007. Finland: IBPSA, 1455-1461.

LU, Y., WU, Z., Chang, R. and Li, Y. (2017). Building information modelling (BIM) for green buildings: A critical review and future direction. Automation in Construction, 83: 134-148. https://doi.org/10.1016/j.autcon.2017.08.024.

Lutzkendorf, T. and Balouktsi, M., ed. (2016). Guidelines for Designers and Consultants: Part 1; Basics for the Assessment of Embodied Energy and Embodied GHG Emissions. Tokyo: Institute for Building Environment and Energy Conservation.

Ng, L.C., Persily, A.K. and Emmerich, S.J. (2015). Improving infiltration modeling in commercial building energy models. Energy Building, 88(1): 316-323. https://doi.org/10.1016/j.enbuild.2014.11.078.

Noor, A.B. and Yi, S. (2018). Review of BIM literature in construction industry and transportation: Meta-analysis. Construction Innovation, 18(4): 433-452. https://doi.org/10.1108/Cl-05-2017-0040.

Olofsson, T., Andersson, S. and Sjögren, J.U. (2009). Building energy parameter investigations based on multivariate analysis. Energy and Buildings, 41(1): 71-80. https://doi.org/10.1016/j.enbuild.2008.07.012.

Olowa, T.O.O., Witt, E. and Lill, I. (2019). BIM for construction education: Initial finding from a literature review. In I. Lill and E. Witt (eds.), 10th Nordic Conference on Construction Economics and Organization (Emerald Reach Proceedings Series, Vol. 2). Bingley, England: Emerald Publishing Limited, 305-313. https://doi.org/10.1108/S2516-285320190000002047

Pan, Y., Yin, R. and Huang, Z. (2008). Energy modeling of two office buildings with data center for green building design. Energy and Building, 40(7): 1145-1152. https://doi.org/10.1016/j.enbuild.2007.10.008.

Pezeshki, Z., Soleimani, A. and Darabi, A. (2019). Application of BEM and using BIM database for BEM: A review. Journal of Building Engineering, 23: 1-17. https://doi.org/10.1016/j.jobe.2019.01.021.

Praseeda, K.I., Reddy, B.V.V. and Mani, M. (2015). Embodied energy assessment of building materials in India using process and input-output analysis. Energy and Buildings, 86: 677-686. https://doi.org/10.1016/j.enbuild.2014 .10 .042 .

Ramesh, T., Prakash, R. and Shukla, K.K. (2010). Life cycle energy analysis of buildings: An overview. Energy and Buildings, 42: 1592-1600. https://doi.org/10.1016/j. enbuild.2010.05.007.

Reddy, B.V.V. and Jagadish, K.S. (2003). Embodied energy of common and alternate building material and technologies. Energy and Buildings, 35(2): 129-137. https://doi.org/10.1016/S0378-7788/01)00141-4.

Reeves, T., Olbina, S. and Issa, R.R.A. (2015). Guidelines for using building information modeling for energy analysis of buildings. Buildings, 5(4): 13611388. https://doi.org/10.3390/buildings5041361. 
Sartori, I. and Hestnes, A.G. (2007). Energy use in the life cycle of conventional and low-energy buildings: a review article. Energy and Buildings, 39(3): 249-257. https://doi.org/10.1016/j.enbuild.2006.07.001.

Schlveter, A. and Thesseling, F. (2009). Building information model based energy/ exergy performance assessment in early design stages. Automation in Construction, 18(2): 153--163. https://doi.org/10.1016/j.autcon.2008.07.003.

Shoubi, M.V., Bagchi, A. and Barough, S. (2015). Reducing the operational energy demand in buildings using building information modeling tools and sustainability approaches. Ain Shams Engineering Journal, 6(1): 41-55. https://doi.org/10.1016/j.asej.2014.09.006.

Westfall, L.A., Nanduri, M. and Taylor, G. (2003). Estimating the impacts of voluntary programs: Results from a recent study on the Canadian industry program for energy conservation. In ACEEE Summer Study on Energy Efficiency in Industry. Washington DC: American Council for an Energy-Efficient Economy (ACEEE), 253-260.

Witte, M.J., Henninger, R.H., Glazer, J. and Crawley, D.B. (2001). Testing and validation of new building energy simulation program. In Building Simulation: Seventh International IBPSA Conference. Rio de Janeiro: IBPSA, 353-360. Available at: http://www.ibpsa.org/proceedings/bs2001/bs01_0353_360.pdf.

Wong, J.K.W. and Zhou, J. (2015). Enhancing environmental sustainability over building life cycles through green BIM: A review. Automation in Construction, 57: 156-165. https://doi.org/10.1016/j.autcon.2015.06.003.

Yung, P., Lam, K.C. and Yu, C. (2013). An audit of life cycle enery analyses of buildings. Habitat International, 39(1-8): 43-54. https://doi.org/10.1016/ j.habitatint.2012.10.003.

Zhang, C., Nizam, R.S. and Tian, L. (2018). BIM-based investigation of total energy consumption in delivering building $\mathrm{T}$ products. Advanced Engineering Informatics, 38: 370-380. https://doi.org/10.1016/j.aei.2018.08.009. 